\title{
二材質分割ブラシの整流特性
}

松田敏彦，鈴木好夫，笹波直樹

(平成 3 年 4 月 2 日受理)

\section{Commutating Capability of Dual-Grade Split Brush}

\author{
Toshihiko Matsuda, Yoshio Suzuki and Naoki Sasanami \\ Department of Electrical and Electronic Engineering, \\ Muroran Institute of Technology, \\ 27-1 Mizumoto-cho, Muroran, Hokkaido, 050, Japan
}

The dual-grade split brush is composed of a low-resistivity leading component and a high-resistivity trailing one. The commutating capability has been studied through the numerical analysis of sparkless zone and the running tests with a $3 \mathrm{~kW}$ DC machine.

To do the numerical analysis, eight suppositive sample brushes which have the same contact resistance and the different ratio of $\mathrm{Rb}_{1} / \mathrm{Rb}_{2}$ are used. Where $\mathrm{Rb} 1$ is the contact resistance of the leading component and $\mathrm{Rb} 2$ the one of the trailing component. For the running tests, ten sample brushes are used. These brushes are made up from the various combination of four kinds of electrographite grades and one copper-graphite grade. And the sparkless zone of these brushes have been measured.

The results are the following. The commutating capability of the dual-grade split brush, like the monoblock one, becomes better as the contact resistance grows higher. With almost the same contact resistance, the dual-grade split brush shows better capability than the monoblock one. And under the same conditions, the abrasion of the former brush is about $1 / 2$ of the latter one.

KEYWORDS: Carbon brush, Dual-grade split brush, Commutation, Abrasion, Contact resistance

\section{1. 緒 言}

直流機抢よび交流整流子機に用いられるカーボン・ブ ラシの整流性能向上の研究は, 古くから行なわれ, 主と して材料の物理的抢よび機械的性質について多くの成果 を得てきている1)。さらに, てれら材料物性面の研究開発

室蘭工業大学電気電子工学科 : $\overline{\boldsymbol{T}} 050$ 北海道室蘭市水元 町27-1
に加えて, 材質の複合構成あるいは分割ブラシのような 形状構成等についての考案が行なわれ, 実用もされてき ている2)。乙れに対し回転方向前部素片に低抵抗材, 後 部素片に高抵抗材を用いる二材質分割ブラシは, 整流特 性が良いと考えられているにあかかわらず, 実用例は筆 者の知る範囲では見られないようである31,4)。

本報告は, この二材質分割ブラシの整流特性について, 特性の予測計算扔よび $3 \mathrm{~kW}$ 直流機による実用試験を行な ったものである。その結果, 二材質二分割および三分割 
ブラシの適用の考え方を示し，実験結果からその有効な 構成が可能であるととを示すあのである。

\section{2. 数值解析による特性考察}

一材質分割ブラシは，素片が自由に動作しうることか ら優れた坐乗性を示す外に，素片間接触抵抗により整流

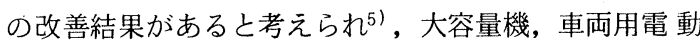
機等に使用されてきている。一方，二つ以上の材質によ りブラシ後端部に高抵抗材質を配置する成層ブラシは, 整流周期後半におりる短絡電流変化率を低く抑えるとい う整流特性の考察加考案されたものと考えられる。し かし, 製法が難しく, 接着面の “はがれ”や接着層によ る接触面荒損の恐れがあるととなどから，実際に使用さ れたという例は少ないようである2）以上により，分割 ブラシと成層ブラシの特長を組み合せた二材質分割ブラ シは良い整流特性を示すであろうと推測される。しかし， この二材質分割ブラシの特性を実用の見地から具体的に 計算解析したり，実験により評価した報告は筆者らの知 る限りでは見あたらないようである。

以下, 実験に用いた $3 \mathrm{~kW}$ 直流機とそのブラシを想定し た基本的な整流回路モデル，すなわち，簡単のためブラ シ厚さが整流子片幅に等しく整流コイルが1個のみのFig， 1 の整流回路について, ブラシ短絡電流抢よびブラシ後 端接触電圧を求めて考察する $\left.{ }^{61}, 7\right)$ 。

\section{1 供試ブラシと整流回路}

整流回路定数として, 整流時間 ( T) と整流コイル実効 インダクタンス $(\mathrm{L})$ の比を

$\mathrm{T} / \mathrm{L}=50[\mathrm{~S}]$

に仮定し，乙れを全計算に対し一定とした。計算に使用 した 9 個のブラシの構成をTable 1 に示す。乙れら仮想 供試ブラシの考え方は, 各ブラシ素片の厚さは等しく全 厚さの $1 / 2$ あるいは $1 / 3$ とし，

1) 定格電流住対する全面接触抵抗 $\left(\mathrm{R}_{\mathrm{b}}\right)$ が $\mathrm{R}_{\mathrm{b}}=0.02$ $[\Omega]$ 一定, すなわち, 正規化平均リアクタンス電圧 $(r)$ が $\mathrm{r}=\frac{2 \mathrm{I}_{\mathrm{F}} \mathrm{L} / \mathrm{T}}{2 \mathrm{I}_{\mathrm{F}} \mathrm{R}_{\mathrm{b}}}=\frac{\mathrm{L}}{\mathrm{R}_{\mathrm{b}} \mathrm{T}}=1.0$

で, ブラシ素片の接触面導電率 $\left(\sigma_{1}, \sigma_{2}, \sigma_{3}\right.$, Fig. 1 参照 $)$ の比を変えたもの 7 個。ただし, $2 \mathrm{I}_{\mathrm{F}}$ : 定格電機子電流, $\mathrm{R}_{\mathrm{b}}$ : 二分割ブラシの場合について

$$
\mathrm{R}_{\mathrm{b}}=\frac{1}{\sigma_{1} \mathrm{a} A+\sigma_{2}(1-\mathrm{a}) \mathrm{A}}=\frac{1}{\mathrm{a} / \mathrm{R}_{\mathrm{b} 1}+(1-\mathrm{a}) / \mathrm{R}_{\mathrm{b} 2}}[\Omega]
$$

乙てに, $\mathrm{a}=1 / 2, \mathrm{R}_{\mathrm{b} 1}, \mathrm{R}_{\mathrm{b} 2}$ : それぞれ $\sigma_{1}, \sigma_{2}$ の単体ブラシ としての接触抵抗, $\mathrm{A}$ : ブラシ全接触面積。

2) ブラシ素片の接触面導電率の比が $\sigma_{1} / \sigma_{2}=3$ (二分 割ブラシ）拈よび $\sigma_{2} / \sigma_{1}=\sigma_{2} / \sigma_{3}=3$ (三分割ブラシ)
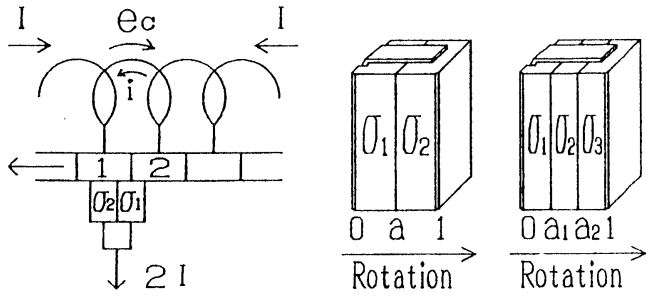

Fig. 1 Commutating circuit and split brushes.

Table 1 Sample brushes for numerical analysis.

\begin{tabular}{|c|c|c|c|}
\hline $\begin{array}{c}\text { Brush } \\
\text { No. }\end{array}$ & $\begin{array}{l}\text { Brush } \\
\text { type }\end{array}$ & $\begin{array}{l}\text { Contact resistance } \\
\qquad \mathrm{Rb}(\Omega)\end{array}$ & $\begin{array}{l}\text { Ratio of } \mathrm{Rbj} \\
\mathrm{Rb} 1: \mathrm{Rb} 2: \mathrm{Rb} 3\end{array}$ \\
\hline 1 & \begin{tabular}{|c|}
$\begin{array}{c}\text { monoblock } \\
\text { brush }\end{array}$ \\
\end{tabular} & 0.02 & $\longrightarrow$ \\
\hline $\begin{array}{l}2 \\
3 \\
4 \\
5\end{array}$ & $\begin{array}{c}\text { dual-grade } \\
\text { double-split } \\
\text { brush }\end{array}$ & $\begin{array}{l}0.02 \\
0.02 \\
0.02 \\
0.04\end{array}$ & $\begin{array}{l}1: 2 \\
1: 3 \\
1: 6 \\
1: 3\end{array}$ \\
\hline $\begin{array}{l}6 \\
7 \\
8 \\
9\end{array}$ & $\begin{array}{l}\text { dual-grade } \\
\text { triple-split } \\
\text { brush }\end{array}$ & $\begin{array}{c}0.02 \\
0.02 \\
0.02 \\
0.036\end{array}$ & $\begin{array}{l}2: 1: 2 \\
3: 1: 3 \\
6: 1: 6 \\
3: 1: 3\end{array}$ \\
\hline
\end{tabular}

で， r が異なるあの 4 個，である。

\section{2 計算結果と考察}

計算結果の一例として, $\mathrm{r}=1.0, \sigma_{1} / \sigma_{2}=3.0$ の二分割 ブラシのブラシ短絡電流曲線およびブラシ後端接触電圧 曲線をFig. 2示す。図において,

$$
c=e_{C} / 2 I_{F} R_{b}, \quad e_{C}: \text { 整流起電力 }
$$

である。ブラシ整流特性の良否判定は, 電気的特性に限 って見ると, 整流終期のブラシ後端接触電圧の大小でな される。すなわち, $v_{2}$ を整流子片 2 とブラシとの接触電 圧とすると，整流の終わり $\mathrm{t} \rightarrow \mathrm{T} の v_{2}$ の値は

$$
v_{2 \mathrm{~T}}=\left[v_{2}\right]_{\mathrm{t} \rightarrow \mathrm{T}}=-\mathrm{R}_{\mathrm{b}} \mathrm{I}_{\mathrm{F}}[\mathrm{di} / \mathrm{dt}]_{\mathrm{t} \rightarrow \mathrm{T}}[\mathrm{V}]
$$

が小さいほど整流が良く, $\left|v_{2 \mathrm{~T}}\right|$ が約 $3[\mathrm{~V}]$ を超えると ブラシに火花を生ずると判断するととができる。

計算結果の考察から, 二材質分割ブラシの整流特性に ついて次のてとが知られる。ただし, 実際の運転条件, すり接触の機械的条件等を考慮しない考察結果であるて とを特に付記する。

1）二材質分割ブラシにおいても，単体ブラシの場合 と同様に, すり接触通電作用など使用条件の許容範用内 でブラシ全面接触抵抗が大きいほど整流特性が良い。

2）全面接触抵抗が等しい場合，二材質分割ブラシは 単体ブラシよりあ良い整流特性を持つ。別の見方をする 


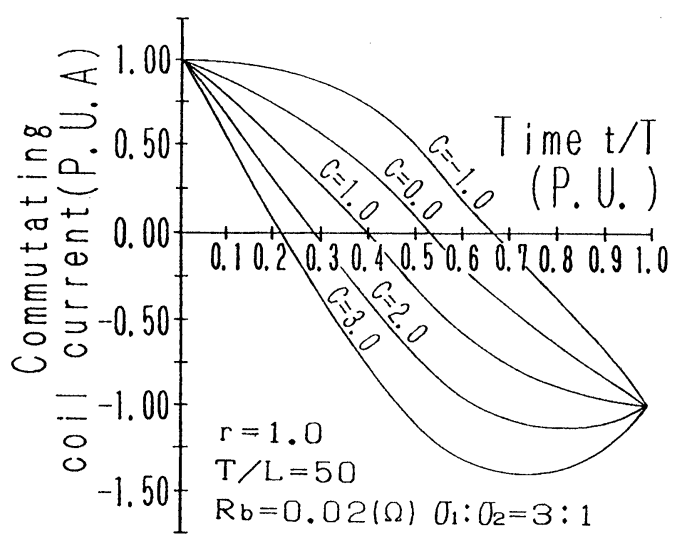

(a) Commutation curve

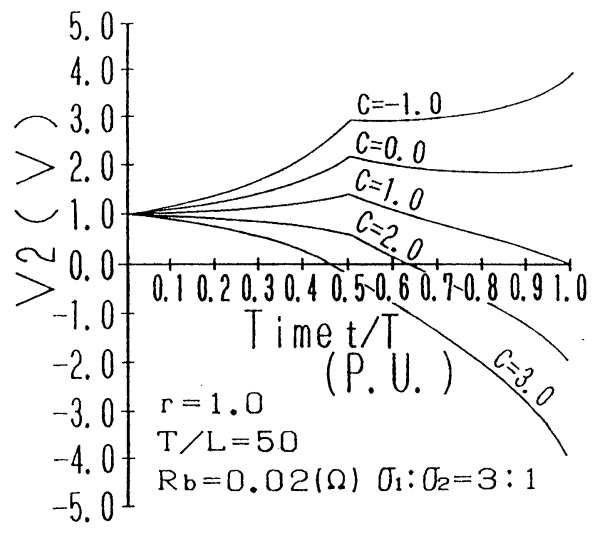

(b) Contact voltage drop

Fig. 2 Calculated commutation curve and brush contact voltage drop of dual-grade double-split brush.

Table 2 Trailing edge contact voltage of sample brushes at the end of commutation by numerical analysis.

\begin{tabular}{c|c|c|c|c}
\hline $\begin{array}{c}\text { Brush } \\
\text { No. }\end{array}$ & $\begin{array}{c}\text { Brush } \\
\text { type }\end{array}$ & $\begin{array}{c}\text { Values of } \\
\mathrm{r}\end{array}$ & $\begin{array}{c}\text { Values of } \\
\left|v_{2 \mathrm{~T}}\right|\end{array}$ & $\begin{array}{c}\text { Ranking of } \\
\text { commutation }\end{array}$ \\
\hline 1 & $\begin{array}{c}\text { monoblock } \\
\text { brush }\end{array}$ & 1.0 & 23.5 & 7 \\
\hline 2 & dual-grade & 1.0 & 11.6 & 5 \\
3 & 1.0 & 8.0 & 3 \\
4 & double-split & 1.0 & 5.6 & 1 \\
5 & brush & 2.0 & 25.5 & 7 \\
\hline 6 & & 1.0 & 13.9 & 6 \\
7 & dual-grade & 1.0 & 8.9 & 4 \\
8 & triple-split & 1.0 & 6.0 & 2 \\
9 & brush & 1.8 & 22.5 & 7 \\
\hline
\end{tabular}

Table 3 Physical costants of the sample brushes on experiment.

\begin{tabular}{c|c|c|c|c}
\hline Symbol & Grade & $\begin{array}{c}\text { Resistivity } \\
(\mu \Omega \text {-cm) }\end{array}$ & $\begin{array}{c}\text { Shore } \\
\text { hardness }\end{array}$ & $\begin{array}{c}\text { Coef. of } \\
\text { friction }\end{array}$ \\
\hline $\mathrm{E} 1$ & $\begin{array}{c}\text { Electro- } \\
\text { graphite }\end{array}$ & 6400 & 48 & 0.20 \\
$\mathrm{E} 2$ & $\begin{array}{c}\text { Electro- } \\
\text { graphite }\end{array}$ & 1100 & 46 & 0.24 \\
$\mathrm{E} 3$ & $\begin{array}{c}\text { Electro- } \\
\text { graphite }\end{array}$ & 900 & 25 & 0.22 \\
$\mathrm{E} 4$ & $\begin{array}{c}\text { Electro- } \\
\text { graphite } \\
\text { Metallic } \\
\text { carbon }\end{array}$ & 3500 & 56 & 0.23 \\
$\mathrm{M} 1$ & 8 & 11 & 0.15 \\
\hline
\end{tabular}

と, 二材質分割ブラシの後部ブラシ素片の材質と単体ブ ラシの材質が同じならば, 分割ブラシの全面接触抵抗 $\mathrm{R}_{\mathrm{b}}$ は単体ブラシよりあ低いが, 整流特性は単体ブラシ之同 等あるいはそれ以上の特性を得る可能性がある。

3）計算に用いた全ブラシの整流性能を, 整流終期の ブラシ後端接触電圧の絶対值 $\left|v_{2 \mathrm{~T}}\right|$ の大小により比較す

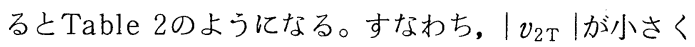
整流が良い順位は表示の通りで, 上記の 1)，2）の特性 を示している。ただし, 整流終期の $\left|v_{2 \mathrm{~T}}\right|$ の值は, $\mathrm{t} / \mathrm{T}$ $=0.999$ における值である。

\section{3. 二材質分割ブラシの整流特性実験}

二材質分割ブラシの整流性能と実用可能性を検討する ため, 13個の供試ブラシについて無火花带測定試験を行 ない考察した結果を示す。

\section{1 実験方法}

供試ブラシの物理定数および構成をTable 3 および Table 4 に示す。使用直流機は, $3 \mathrm{~kW}$ 他励発電機, 2 極, $100 \mathrm{~V}, 30 \mathrm{~A}, 1500 \mathrm{rpm}$, ブラシ寸法 $12.5 \times 20 \times 32$ $\mathrm{mm}^{3}$ で, 補極添加励磁券線およびブラシ短絡 コイル電 流測定回路を持っている。測定方法は, 各ブラシごとに, まず $5 \mathrm{~A}$ の小電流で約20時間の予備運転を行ない, 次に 各測定点（電機子電流設定）につき 1 時間の安定化運転 を行ない, 目測により 3 号火花発生限界補極添加電流を 測定した。各ブラシについて, 測定日を変えて 4 〜回 の測定を行ない, その平均の無火花帯を測定結果とした。

\section{2 実験結果}

測定結果の例として, 以下負ブラシの測定結果のみを 
Table 4 Samples of dual-grade split brush for experiment.

\begin{tabular}{c|c|c|c}
\hline Brush type & Symbol & $\begin{array}{c}\text { Grade of pieces } \\
\text { of a brush }\end{array}$ & Remark \\
\hline $\begin{array}{c}\text { monoblock } \\
\text { brush }\end{array}$ & S1 & E1 & \\
& S2 & E2 & \\
\hline S3 & E3 & \\
$\begin{array}{c}\text { doubl-grade } \\
\text { brush }\end{array}$ & D1 & E4/E4 & round top \\
& D2 & E4/E4 & flat top \\
& D3 & E2/E2 & flat top \\
& D4 & E3/E1 & flat top \\
& D5 & E2/E1 & flat top \\
& D6 & M1/E1 & flat top \\
& M1/E2 & flat top \\
\hline dual-grade & T1 & E1/E2/E1 & flat top \\
triple-split & T2 & E1/E3/E1 & flat top \\
brush & T3 & E1/M1/E1 & flat top \\
\hline
\end{tabular}

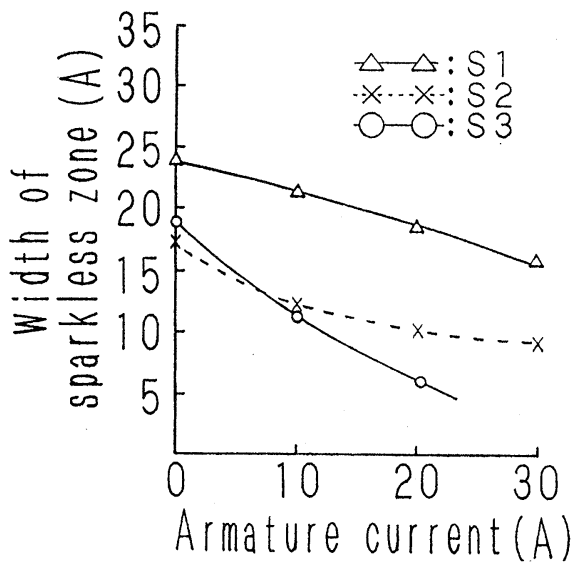

Fig. 3 Width of sparkless zone at rated current density of sample monoblock brushes.

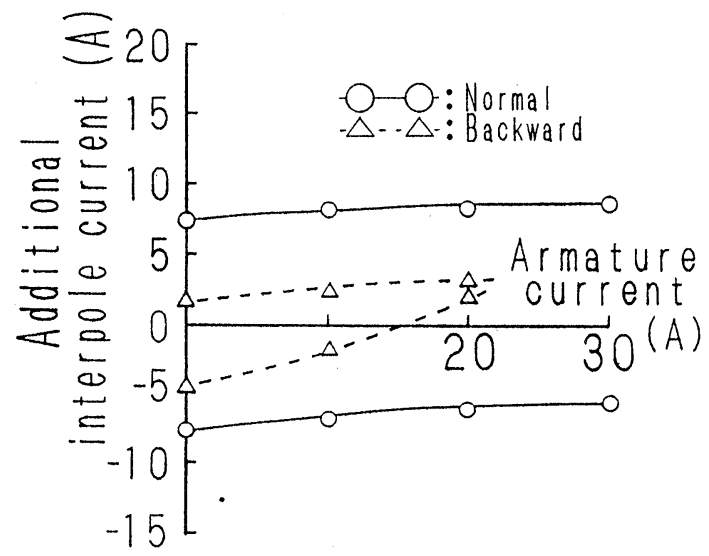

Fig. 4 Comparison of sparkless zone of dualgrade double-split brush by normal and backward rotation.
示し，正ブラシ測定結果の表示は省略する。一般に，正 ブラシの無火花帯は負ブラシより若干狭く測定されるが, 各ブラシを比較した整流特性の良否関係は負ブラシと同 一で,ブラシ極性により変わらない。

1）Fig. 3に 3 個の供試単体ブラシの無火花带幅を比 較して示した。縦軸は正と負の無火花帯限界線間の幅を とってプロットしたものである。㼟から， $\mathrm{R}_{\mathrm{b}}$ の大きい順 に無火花帯が広いととが分かる。

2）二材質二分割ブラシの材質効果を確認するため, 二分割ブラシD７亿ついて回転方向を変えて無火花帯を 測定した。その結果をFig.4亿示す。図中実線の無火花 帯が回転方向後部に高抵抗材質素片を置いたもので, 二 材質を用いた効果が明確に現われている。

以下, 二材質分割ブラシの測定結果はすべて後部素片 高抵抗材質ブラシによるものである。

3）二分割ブラシの無火花帯 Fig.5亿全供試二分割ブ ラシの無火花帯幅測定結果を示す。図から, 二材質二分 割ブラシの無火花帯について次のてとが知られる。

a) $R_{b}$ の值が同じ程度ならば, 二材質二分割ブラシは 単体ブラシおよび同一材質二分割ブラシより広い無火花 帯を示す。

b）電機子電流の増加による無火花帯狭まりが少ない。

c）前部ブラシ素片に銅黒鉛質を用いた二分割ブラシ は， $\sigma_{1}$ と $\sigma_{2}$ の比を大きく取ることができるが, $\mathrm{R}_{\mathrm{b}}$ の減 少効果が大きく整流特性は良くない。

4）二材質三分割ブラシの無火花帯 正転, 逆転両用 機に対しては, 前部挍よび後部のブラシ素片に高抵抗材 質を用いた二材質三分割ブラシの使用が考えられる。乙 の二材質三分割ブラシの無火花帯測定結果をFig. 6 亿示 す。特性を要約すると次の通りである。

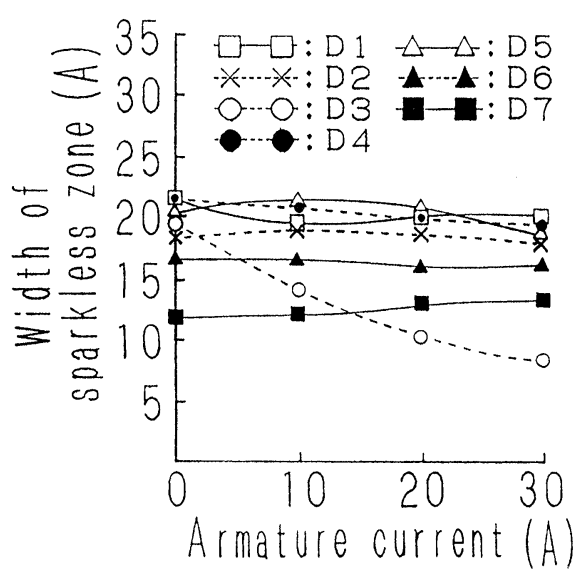

Fig. 5 Comparison of sparkless zone of dualgrade double-split brushes. 
a）単体ブラシおよび二材質二分割に比べ，最も広い 無火花帯を与える。

b）無火花帯の狭まりが少ない。

5）接触電圧降下静特性の測定 参考のため, 二分割 ブラシの接触電圧降下曲線の測定を行なった。その結果 を一括してFig. 7 亿示す。ほほ，各ブラシ材質の抵抗率 の大小の順序の電圧降下值を与えている。なお, 単体ブ ラシ S 1 拈よび三分割ブラシ T 1 , T 2 の電圧降下曲線は 二分割ブラシ D 2, D 30曲線とほぼ同等に得られた。ま た, 三分割ブラシT 3 の曲線はD 6,D 7 の曲線とほぼ同 じに得られた。

\section{3 考 察}

従来、二材質分割ブラシは, 後部高抵抗素片の短絡電

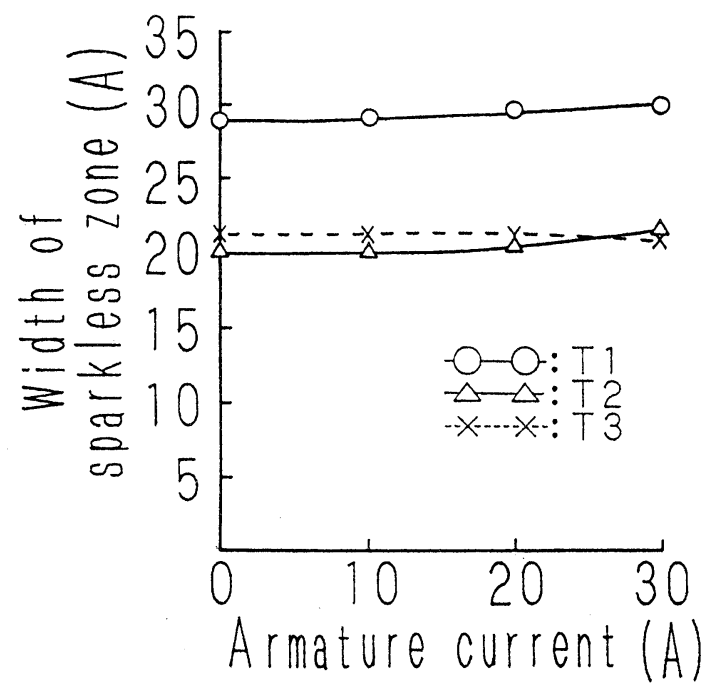

Fig. 6 Comparison of sparkless zone of dualgrade triple-split brushes.

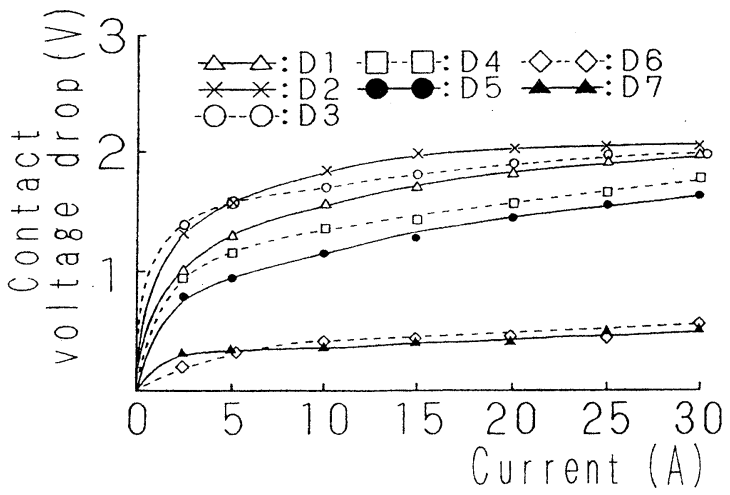

Fig. 7 Contact V-I characteristics of dual-grade double-split brushes.
流抑制効果の推測から, 無条件に単体ブラシより良い整 流特性を持つと考えられていたようである。しかし，上 記の数値解析および実験により,

1）二材質分割ブラシは全ての単体ブラシより良い整 流特性を持つものではなく, ブラシ全面接触抵抗が同等 ならば，二材質分割ブラシの方がよい整流特性を示す。

2）二材質分割ブラシにおいても，その進み整流特性 を有効に活かすために, 補極強度調整は必要である。

3）二材質分割ブラシはその進み整流特性から, 補極 を持たない小型電動機で，整流インダクタンスが大きく， 遅れ整流運転になる電動機に用いると有効であると考え られる。

\section{4. 二材質二分割ブラシの摩耗試験}

二材質分割ブラシの実用に対して, 最も危惧される点 はブラシの異常摩耗, 整流子すり面の荒損およびブラシ 素片の欠損の問題であろう。乙れらは二分割ブラシに適 する材質の選定とその組合せに対する技術蓄積により克 服しうる問題であると考える。以下，実負荷運転および 摩耗について若干の試験を行なった結果を示す。

\section{1 実験方法}

供試ブラシとして, Table 4の二分割ブラシD 2,D4, D 5, および比較のために単体ブラシ S 1, S 2, S 3 の 6 個 をとりあげた。実験用直流機は整流特性試験に用いたも のと同じ発電機で, 整流子直径 $110 \mathrm{~mm}$, ブラシ加圧力 $200 \mathrm{~g} / \mathrm{cm}^{2}$ である。試験環境は, 室温 $15 \sim 25^{\circ} \mathrm{C}$, 整流子 表面温度 46 ～ $61^{\circ} \mathrm{C}$ であった。整流子すり面の準備は小電 流で約40時間のすり合わせ運転により行なった。

摩耗量の測定は, 電流密度 $6 \mathrm{~A} / \mathrm{cm}^{2}$, 無火花状態で 10 時間の運転毎に, ブラシ重量を精密天秤で測定し,

$$
\text { (摩耗長さ) }=\frac{\text { (摩耗重量) }}{(\text { 見かけ比重 }) \times(\text { すり接触面積 })}
$$

により算出した。乙の測定方法には大気中ガスの吸着, ブラシ保持器からの着脱時の欠損等による誤差が考えら れるが，特にその補正は行なっていない。

\section{2 実験結果と考察}

摩耗試験の供試ブラシ 6 種の 100 時間運転の摩耗長さ （正負ブラシの平均値）をTable 5 に示す。ブラシ素片 間の摩耗長さの差を

(素片間摩耗差) $=$ （前部素片摩耗長さ）

\section{- (後部素片摩耗長さ)}

で表し，その測定結果をFig. 8に示した。実験結果を要 約すると次の通りである。

1）二分割ブラシの摩耗量は単体ブラシの約 $1 / 2$ で ある。

2）二分割ブラシの「素片間摩耗差」は100時間 運転 
Table 5 Abrasion length of sample brushes by $100 \mathrm{~h}$ running.

\begin{tabular}{|c|c|c|c|c|}
\hline \multirow{2}{*}{$\begin{array}{l}\text { Brush } \\
\text { type }\end{array}$} & \multirow{2}{*}{ Symbol } & \multicolumn{2}{|c|}{ Abrasion length $(\mathrm{mm} / 100 \mathrm{~h})$} & \multirow{2}{*}{$\begin{array}{l}\text { Relations } \\
\text { of abrasion length } \\
\text { and running time }\end{array}$} \\
\hline & & Positive brush & Negative brush & \\
\hline $\begin{array}{c}\text { monoblock } \\
\text { brush }\end{array}$ & $\begin{array}{l}\text { S1 } \\
\text { S2 } \\
\text { S3 }\end{array}$ & $\begin{array}{l}0.250 \\
0.335 \\
0.215\end{array}$ & $\begin{array}{l}0.275 \\
0.245 \\
0.240\end{array}$ & $\begin{array}{l}\text { linear } \\
\text { linear, fluctuation on posit. brush } \\
\text { slight saturate }\end{array}$ \\
\hline $\begin{array}{l}\text { dual-grade } \\
\text { double-split } \\
\text { brush }\end{array}$ & $\begin{array}{l}\text { D2 } \\
\text { D4 } \\
\text { D5 }\end{array}$ & $\begin{array}{l}* 0.135 \\
* 0.120 \\
* 0.110\end{array}$ & $\begin{array}{l}* 0.130 \\
* 0.140 \\
* 0.105\end{array}$ & $\begin{array}{l}\text { saturate } \\
\text { linear, fluctuation at } 80-100 \mathrm{~h} \\
\text { linear }\end{array}$ \\
\hline
\end{tabular}

* Mean value of abrasion length of leading and trailing brush.

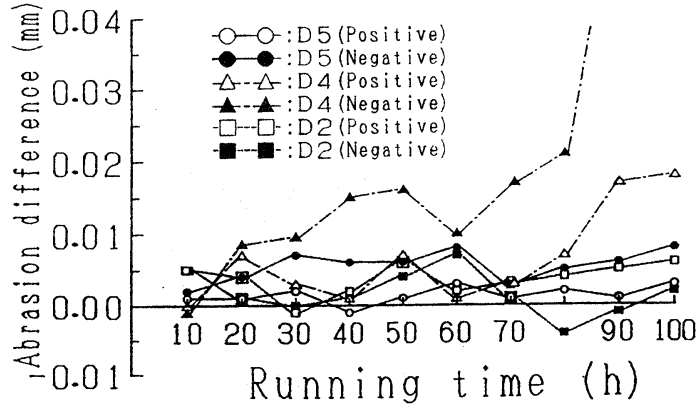

Fig. 8 Abrasion difference of two pieces of a split brush.

により前部素片の摩耗が $0.005 \sim 0.01 \mathrm{~mm}$ 程度大きく生じ た。ただし，D 4 ブラシはFig. 8亿見られるように80〜 100 時間に大きな素片間摩耗差を示した。乙の前部素片 の摩耗量が大きい点とその長時間運転の推移については, 更に詳細な試験が必要と考えられる。

3）各ブラシの実験終了時整流子すり面の状態は, ブ ラシD 2,D 4, D 5 亿ついては目視観察の結果で異常は 認められなかった。ただし，実験結果は示していないが， 銅黒鉛質素片を用いたD 6, D 7ブラシは，後部電気黒鉛 質素片すり面任金属摩耗粉が付着し，整流子すり面にあ 著しい皮膜損傷が観察された。乙の金属黒鉛質と電気黒 鉛質を組み合わせる二材質分割ブラシは，本試験では整 流特性屯良くなく，その適用には十分な検討が必要であ る。

\section{5. 結 言}

二材質分割ブラシの整流特性と実用の可能性を検討す るため, 基本的整流回路モデルによる整流特性数值解析, $3 \mathrm{~kW}$ 直流発電機による無火花帯法整流試験およひ摩耗試
験を行ない，次のような結論を得た。

1）二材質分割ブラシに扔いても, 他の条件から許容 される範井で，ブラシ全面接触抵抗を高くするほど整流 特性が良い。前部素片之後部素片接触抵抗の比の選定は, ての特性との関連を考慮して決める必要がある。

2）単体ブラシおよび単一材質分割ブラシと比較し, ブラシ全面接触抵抗が同じ程度ならば二材質分割ブラシ の方が良い整流性能を持つ。

3）二材質分割ブラシは, 低い接触抵抗で比較的に良 い整流を得たい場合，補極を持たない小型機で，ブラシ の進み整流特性を活用することが望ましい場合などに有 効である。

4）材質の組合せが適切な二材質分割ブラシの摩耗は, 単体ブラシの約 $1 / 2$ という実験結果を得た。後部素片に 比べ前部素片の摩耗量が若干大きい。また本実験例では, 銅黒鉛と電気黒鉛の組合せによる分割ブラシは整流子す り面の荒損を発生した。乙の二材質分割ブラシの摩耗に ついては, 各ブラシ構成でとに確認試験が必要之考えら れる。

\section{文献}

1) 炭素材料学会編, 電機用ブラシとその使い方, 日刊 工業新聞社 (1977).

2) 高橋広治, 炭素 1956 [No. 18] 16.

3) 林邦雄, 畠山一馬, 電学誌 68 [12] 329 (1948).

4) 松田敏彦, 室工大研報 4 [2] 329 (1963).

5) W.B. Belt, Practical Aspect of Brush Contact Stability, A.I.E.E Trans. 73 [2] (1954).

6) 松田敏彦, 鈴木好夫, 電学回転機研究会資料 RM83-69 (1983).

7) 松田敏彦, 松島由太郎, 内藤正本, 藤原一, 電学論 B 97 [6] 337 (1977). 